\title{
ANALYSIS OF GREEN IT PRACTICES IN TECHNOLOGY-BASED ORGANIZATIONS
}

\author{
ANÁLISE DAS PRÁTICAS DE TI VERDE EM \\ ORGANIZAÇÕES DE BASE TECNOLÓGICA
}

Submission: 16/01/2019 Accept: 29/07/2020

\author{
Vanessa Theis ${ }^{1}$ \\ Dusan Schreiber ${ }^{2}$ \\ 1 FEEVALE University
}

\begin{abstract}
Purpose: This paper aims to analyze Green IT practices adopted by technology-based organizations.

Methodology: The study had a quantitative approach and the data were collected through a questionnaire, which was answered by 105 managers working in companies in the IT sector in Brazil

Findings: Evidence collected showed that companies have a reactive behavior towards Green IT because they do not have, as their strategic objective, an increase in the general perception of value that consumers have about the company, nor do they seek competitivess based on sustainable development.

Originality/value: In the Brazilian research scenario, the search for the keywords "Green IT", "Green Information Technology", "Green IT" and "Green Information Technology" on the Scielo search platform, found only five articles, on July 15th, 2020. In a search on the SPELL portal and CAPES Portal of Journals, also on July 15th, using the aforementioned keywords, four articles were found, in addition to those already found on the Scielo portal. Such results demonstrate how the topic is still little explored in the context of research in Brazil. It is important to note that Green IT comes up as a way of combining the available resources with the sustainability and economy policies in organizations, generating benefits for the environment and companies, providing opportunities for new business platforms.
\end{abstract}

Keywords: Green IT; Sustainability; IT industry. 


\section{RESUMO}

Objetivo: Analisar as práticas de TI Verde adotadas por organizações de base tecnológica.

Metodologia: $O$ estudo teve abordagem quantitativa e os dados foram coletados por meio de um questionário, respondido por 105 gestores que atuam em empresas do setor de TI no Brasil.

Resultados: As evidências coletadas mostraram que as empresas têm um comportamento reativo em relação à TI Verde porque não têm como objetivo estratégico um aumento na percepção geral de valor que os consumidores têm sobre a empresa, nem buscam competitividade com base no desenvolvimento sustentável.

Originalidade/Valor: No cenário da pesquisa brasileira, a busca pelas palavras-chave "TI Verde", "Tecnologia da Informação Verde", "TI Verde" e "Tecnologia da Informação Verde" na plataforma de busca Scielo, encontrou apenas cinco artigos, no dia 15 de julho de 2020. Em busca no portal SPELL e Portal de Periódicos da CAPES, também no dia 15 de julho, utilizando as palavras-chave citadas, foram encontrados quatro artigos, além dos já encontrados no portal Scielo. Tais resultados demonstram como o tema ainda é pouco explorado no contexto das pesquisas no Brasil. É importante destacar que a TI Verde surge como uma forma de aliar os recursos disponíveis às políticas de sustentabilidade e economia nas organizações, gerando benefícios para o meio ambiente e as empresas, oportunizando novas plataformas de negócios.

Palavras-chave: TI Verde; Sustentabilidade; Setor de TI.

\section{INTRODUCTION}

The evolution of Information Technology (IT) is mainly linked to the scientific and technological advances and pressures of an increasingly competitive market environment. The development of new technologies has generated the configuration of new scenarios, as well as opportunities for companies to advance in the process of offering products and services. Therefore, the perception that IT cannot be dissociated from business activities is increasingly intense, since it serves as an instrument to support the incorporation of knowledge as the main value added to products, processes, and services delivered to customers.

On the other hand, IT has represented a significant and growing part of the environmental problems that society is currently facing, since, as companies become more dependent on IT services, the factors regarding availability and continuity of services increase exponentially, multiplying the requirements of equipment and structure. Thus, as environmental problems become more evident, a new approach from managers is required and the need to design and operationalize a new corporate social responsibility arises, characterized by the concern to reduce pollution and energy expenditure in the development of products and services (Bohas and Poussing, 2016). In the IT industry, this movement has been called Green Information Technology, or simply, Green IT.

The concept was first used by Elliot (2007), and to the author Green IT is considered as the complete life cycle of information and communication technologies, involving environmentally correct processes of design, production, operation, and disposal. This is due to the fact that Green IT incorporates the environmental aspect of sustainability, with respect to energy efficiency (Uddin and Rahman, 2012; Fang et al., 2015; Chung, 2017; Kurkalova and Carterb, 2017), to plan and invest in a technological infrastructure that meets the needs of current generations, conserving the resources needed for future generations (Elkington and Burke, 1987; Pollack, 2008), generating benefits for the environment, for companies and for the society (Elliot, 2007). Thus, this research aims to analyze the Green IT practices adopted by Brazilian technology-based organizations.

Although the environmental effects of IT have been a catalyst for the growth of Green IT, Asadi, Hussin and Dahlan (2017) point out that few empirical studies have been carried out in this field, which justifies the study's theme. The aforementioned authors found that the majority of studies have been carried out in developed countries, and suggest that the growing business opportuni- 
ties, with the IT intensive, have highlighted the need to make IT environmentally friendly. However, Hanne (2011) points out that this field of research is of interest to developing countries, as it offers new business opportunities with economic, social and environmental benefits. Therefore, it is essential to expand research on Green IT in these regions, where imminent industrialization increases global environmental costs.

In the Brazilian research scenario, the search for the keywords "Green IT", "Green Information Technology", "Green IT" and "Green Information Technology" on the Scielo search platform, found only five articles, on July $15^{\text {th }}, 2020$. It is noteworthy that the search for words was carried out in the title field, without any filter in relation to the year of publication, according to the availability of that database. Based on an interview with ten managers, the first article seeks to understand how institutional pressures and environmental beliefs of managers influence the adoption of Green IT in higher education institutions (Dias et al., 2017). The second study analyzes the adoption of Green IT in three companies from different economic sectors, examining, more specifically, the reasons for adoption, the practices implemented, the perceived benefits and the difficulties faced (Salles et al., 2016).

The following article explains the dynamics of the implementation of Green IT in organizations from a structuralist perspective of technology, through a study of multiple cases in three Brazilian companies (Dolci et al., 2015). The authors Lunardi, Alves and Salles (2014), developed an instrument to assess the degree of use of Green IT by organizations. Finally, Lunardi, Simões and Frio (2014), sought, in their research, to identify and analyze the main benefits and practices of Green IT adopted by organizations.

In a search on the SPELL portal and CAPES Portal of Journals, also on July $15^{\text {th }}$, using the aforementioned keywords and without delimitation when at the time of publication, four articles were found, in addition to those already found on the Scielo portal. These articles have similar objectives to those already mentioned above. It should be noted that, as with the search platforms Science Direct and EBSCO, no publications were found on similar Brazilian research platforms with the specific focus of this paper.

It is important to note that Green IT comes up as a way of combining the available resources with the sustainability and economy policies in organizations, generating benefits for the environment and companies, providing opportunities for new business platforms. Therefore, the research will contribute to the progress of scientific knowledge, in addition to analyzing the solutions to the problems generated by the extensive use of information technology, since most computing resources attack the environment due to the high consumption of electricity, quantity of non-renewable inputs used in the production of computers and peripherals, in addition to the inappropriate disposal of obsolete equipment.

After this introduction, the paper presents theoretical approaches about corporate sustainability and Green IT, followed by the methodological procedures and discussion of the results. After the description and presentation of the corpus, the final considerations regarding the objectives of the research, its contributions, limitations and suggestions for future research are described.

\section{LITERATURE REVIEW}

In order to contemplate the study proposal, this section presents the conceptual bases on the concept of corporate sustainability and the concepts of Green IT. 


\subsection{Corporate Sustainability}

The Brundtland Report (1987) established the concept of sustainable development, combining economic growth with social development. In the report, the concept of sustainable development suggests the adoption of a development model that can meet the needs of the present without compromising the ability of future generations to meet their own needs. In short, sustainable development provides for the conscious use of natural resources, aiming at the growth of countries, combating poverty and ensuring meeting basic human needs (Brundtland et al., 1987).

Thus, it is evident that the relationship between economic development and the environment arises with the depletion of natural resources, from the expansion of economic activity. These issues have even intensified the attention of consumers, ecological organizations and regulators on the negative environmental impact of companies: greenhouse gas emissions, contamination by waste and inefficient use of water and energy (Elkington and Burke, 1987).

In the year that the Brundtland Report was published, English sociologist John Elkington coined the term sustainability through his work The Green Capitalists. For the aforementioned author, sustainability is, in reality, a business management model that aims at profit for shareholders, involving, at the same time, economic development, social promotion and protection of the planet's natural resources. This management model was called, by the author, the Triple Bottom Line, and comprises the results of an organization, measured in social, environmental and economic terms (Elkington and Burke, 1987).

Deepening the debate on the Triple Bottom Line concept, Dyllick and Hockerts (2002) show that corporate sustainability can be defined as meeting the needs of all stakeholders, without compromising the ability to meet the needs of future stakeholders. To this end, companies need to maintain, and expand, their economic, social and environmental capital base, actively contributing to sustainability in the political domain. It is noteworthy that the most important contribution of the concept of sustainability, in orthodox management theory, lies in its perception that economic sustainability, by itself, is not a sufficient condition for the overall sustainability of a company.

In summary, the global challenges associated with sustainability, seen from the business perspective, can help to identify strategies and practices that contribute to a more sustainable world and, simultaneously, boost shareholder value, thus representing the source of creation of sustainable value for the company. Furthermore, Hart and Milstein (2003) clarify that the opportunities to create sustainable value are enormous, but still little explored, because, although they have a simple structure, the execution strategies tend to be complex and challenging, suggesting that the initiatives should be evaluated using a separate set of criteria and metrics, since they are unlikely to meet the short-term revenue and profitability targets associated with what was designed to expand existing businesses.

Hubbard (2009) corroborates this perception, when stating that measuring organizational performance in relation to sustainability practices is not an easy task, due to the lack of a consensus regarding the concept of sustainability and, also, regarding the scope of the options for sustainability. measurement. Generally, Triple Bottom Line's environmental measures refer to the amount of natural resources that a company uses in its operations, such as energy, land and water, as well as the by-products that its activities create, such as, for example, waste, atmospheric emissions and chemical waste. Social performance highlights the impact that a company and its suppliers bring on the communities in which it works.

New social expectations also make it imperative for companies to understand how to integrate sustainability issues into business strategies, and therefore into their products. In this perspective, Dangelico and Pujari (2010) clarify that several benefits can arise from the integration of 
environmental sustainability issues to the development of products and commercial operations: greater efficiency in the use of resources, return on investment, increased sales, development of new markets and better corporate image. The authors also state that environmental regulations not only represent regulatory constraints or compliance, but offer opportunities for minimizing risks, preserving revenues and reputation or creating new businesses.

Aguinis and Glavas (2012), point out that companies are involved in sustainability practices due to the expected financial results, for normative reasons linked to the company's values, best management practices, product quality, operational efficiency, attractiveness for investors and greater demographic diversity. Institutional forces, including regulations, standards and certifications, also affect the extent and types of sustainability actions and policies that companies decide to implement. With regard to the effects of the relationship between initiatives and results, it can be seen that the results are more effective when the stakeholders have more power and legitimacy and in the presence of greater regulation.

Broadening the debate about the definition of sustainability, Baumgartner (2014) bases it on the concept of eco-efficiency, where economics and ecology are combined to provide sustainable goods and services. The objective is that ethics, equity and justice are the central focus of the normative interpretation of sustainable development, since to meet the needs of present and future generations these three principles must be considered. The authors list that the equal rights of people to environmental resources and the social responsibility of companies for future generations, are based on the concept of eco-equity.

In addition, several elements are needed to develop corporate sustainability structures, as each definition offers specific views. Legitimizing corporate activities, both within a company and in society, is fundamental to business and requires responsible and ethical corporate behavior (Baumgartner, 2014). Martínez-Jurado and Moyano-Fuentes (2014), conclude that the increasing pressure from interested parties has an influence on decisions about which strategies the company will adopt in order to manage its business in a responsible manner and aware of the impacts that its activities represent in the society and, therefore, increasing its corporate social responsibility.

In view of the above, it is understood that sustainability practices demand actions that can be reproduced and that allow interaction with organizational phenomena. Thus, the fact that sustainability is a state achieved by actions, organizational sustainability practices involve aspects related to human relations and different entities in society and the environment, therefore, they are guided by a series of values. These non-financial values represent a major challenge in today's business models, as the needs imposed by the modern corporate world have forced companies to think about alternatives for more and more efficient management.

In this sense, companies can increase their differentiation in the market through intangible earnings associated with Green IT (Crittenden et al., 2011). This is reflected in actions of eco-equity and eco-effectiveness, which make it possible to act proactively with regard to aspects of socioenvironmental responsibility with future generations, not being limited only to act in an environmentally correct manner to meet environmental legislation or in favor of financial benefits direct. Therefore, IT can drive companies towards ecological sustainability, by introducing innovations that change the logic of commercialization or use of products or services (Chen et al., 2011).

\subsection{Green Information Technology}

Conceptually, Elliot (2007) points out that Green IT is considered as the complete life cycle of information and communication technologies, involving environmentally correct processes of design, production, operation, and disposal (Elliot, 2007). It is evident that the Green IT concept has 
been used as a generic term for IT-related measures and activities that seek to contribute to environmental sustainability and corporate social responsibility (Chen, Boudreau and Watson 2008) and not only with issues of conscious consumption (Fuchs, 2008).

This happens because Green IT incorporates the environmental aspect of sustainability into energy efficiency, planning and investments in a technology infrastructure that meets current needs, conserving the resources needed for future generations, and saving money (Pollack, 2008). It is noteworthy that in conceptual terms, Molla et al. (2009) propose that Green IT is an organization's ability to systematically apply environmental sustainability criteria such as pollution prevention, product management and use of clean technologies, in the processes of production, supply, use and disposal of IT technical infrastructure.

In this context, Sarkar and Young (2009) point out that organizations are being more demanded and pressured by government regulators and environmental watchdogs to align their business with environmental sustainability practices. In addition, Kuo and Dick (2010) add that competitive market pressures also influence the decision to adopt environmentally sustainable practices and believe that the main factor of the competitive differential in this scenario is the ability of the organization to adapt to a new reality and new technologies.

Mithas, Khuntia and Roy (2010) also argue that the implementation of Green IT is positively associated with greater reductions in the energy consumption of IT equipment and, consequently, greater impact on profits. It should be noted that Watson, Boudreau and Chen (2010) understand that pursuing sustainability does not mean abandoning economic thinking. The economy points to the problem of allocating scarce resources, and resources such as the energies free from gas emissions and electro-electronic components are particularly scarce. Therefore, intelligent technology management is an alternative to companies to reduce environmental damage, improve the effectiveness of electric power consumption, and reduce business-operating costs (Melville, 2010).

Regarding the importance of high management involvement, with the environmental strategies of the company, Schmidt et al. (2010) emphasize that environmental and IT managers can drive the Green IT issue by actively addressing the IT department and creating appropriate configurations in the context of an environmental strategy. On the other hand, if the company's needs and environmental strategy are not congruent with Green IT ideas, the chances of adoption seem to be limited. Thus, making decision-makers and individuals realize the benefits of actions for the environment is essential to creating more sustainable processes and practices in organizations (Melville, 2010).

In Corbett's (2010) view, Green IT is defined as the set of information and communication technologies and information systems that are directly or indirectly used to reduce the harmful environmental impacts of human activities. For organizations, Green IT happens through of the initiatives relate with the acquisition of energy-efficient hardware, end-user energy management, recycling and waste reduction, teleconferencing practices, information virtualization, data center design and management, carbon management systems and environmental reporting. The authors Dick and Burns (2011) point out that the economy in paper consumption is one of the most widespread Green IT practices among organizations.

Another Green IT practice refers to the recycling and disposal of equipment, in which obsolete electronic devices can be reused by other organizations (Fairweather, 2011). Regarding the destination of electronic equipment, Act 12.305, sanctioned on August 2, 2010 in Brazil, instituted the National Solid Waste Policy (NSWP) and regulates the final destination of solid waste in the country, also addressing questions about the end destination of the electronic waste or reverse logistics of finished products, such as those of the digital industry segment. According to the NSWP, reverse logistics is the instrument of economic and social development characterized by a set of actions, 
procedures and means to enable the collection and restitution of solid waste to the business sector, since the manufacturers know more about the product and its production process than consumers and will be able to develop strategies for their dismantling and reuse (Brasil, 2010).

Unhelkar (2011) points out that managers need to improve the organization's energy efficiency through innovative management strategies, and these strategies need to combine operational costs with the carbon emissions spent by datacenters. Regarding IT infrastructure, the author cites the use of data storage virtually in order to reduce energy consumption. Through the Internet, it is possible to create virtual work environments and the benefits are measured, not only in reducing energy consumption but also in reducing depreciation and maintenance costs (Unhelkar, 2011; Butler, 2011).

In view of the above, Loos et al. (2011) point out that the world faces an ecological crisis in the form of global warming, resulting from $\mathrm{CO} 2$ emissions. They defend the investments in research on how to improve IT energy efficiency, with a particular focus on reducing energy consumption by developing practical solutions that leverage the power of transformation of information systems. To the detriment of this scenario, Molla and Abareshi (2011) found in their research that the reasons for eco-efficiency and eco-efficacy influence the adoption of technologies that improve the energy efficiency of IT infrastructure and subsequent reduction of pollution.

In practical terms, the fact that eco-efficiency and eco-efficacy are important determinants of the adoption of Green IT implies that there are tangible positive gains in terms of costs and intangible benefits such as leadership and the dissemination of environmental thinking associated with Green IT. Molla and Abareshi (2012) add that although some of the practices require high investments, most of them can be adopted without compromising the financial health of the company, only depending on the effort and willingness of the users and the support and direction of the organization.

It is emphasized that eco-efficiency is aligned with organizational efficiency and profitability. Reducing energy consumption and resource use is clearly a way to reduce costs and improve revenue. However, in order to achieve an environmentally sustainable organization, managers need to think and act proactively, seeking solutions beyond conventional Green IT practices, not just by acting in an environmentally sound way for financial benefits or to comply with environmental regulations. In this sense, Chen et al. (2011) indicate that eco-effectiveness aims to solve the environmental issue, regardless of financial viability. Therefore, IT can transform a company towards ecological sustainability by inserting innovations that change the logic of marketing or use of products or services.

Focusing on internal and external motivational factors, Molla and Abareshi (2011) inferred that when regulatory and market mechanisms are not sufficiently strong or unclear to encourage the adoption of Green IT, managers who aim at regulatory compliance will likely benefit by investing in Green IT. However, employees' perceptions and attitudes are just as equal, if not more important, as the management commitment and the allocation of resources in the transformations towards a sustainable IT operation. Thus, organizations can take advantage of their employees' values and care about the environment to identify Green IT opportunities and encourage green innovations.

Chen and Chang (2013) warn that consumers are more attentive to companies attempting to enter environmental values through the use of marketing techniques in order to create a non-existent image about the degree of environmental responsibility to stakeholders and customers. To the detriment of this reality, Cai, Chen, and Bose (2013) elucidate that the significant effect of Green IT goes beyond cost reduction. The proper use of Green IT principles for environmental sustainability reinforces market differentiation as it improves products and processes, increases market share, or 
makes it possible to enter new and more profitable markets. Summarizing, with the proper use of IT-related systems and equipment, a company can improve its competitiveness and remain environmentally friendly.

Regarding the behavior of individuals, in order to adopt the practices of TI Verde, Mishra, Akman and Mishra (2014) observed that the professionals who identify the value of TI Verde consider the issues of environmental sustainability during the purchase of hardware and software. In addition, the authors verified different attitudes of employees of public and private sector companies, regarding the acceptance and implementation of Green IT. Bureaucratic procedures are presented as a restriction for professionals in government companies. On the other hand, professionals in the private sector tend to optimize resources better and propose more economical and innovative solutions. In short, it can be inferred that the level of awareness of employees has a significant impact on the attitude, intention and real behavior in the adoption of Green IT.

In this context, Koo, Chung and Nam (2015) highlight that the individual's intention to manifest such behavior, appears only when the attitude, the subjective norm and the perceived behavioral control are also significant. In this sense, the perceived usefulness of Green IT practices has positive effects on behavior and on the intention to continue its application and use in decision-making processes. In addition, organizations that wish to succeed in the continuity of Green IT in organizational processes, need to develop persuasion techniques that modify the intentions of employees, with attention to attitudes, subjective norms and perceived control over behavior.

According to Akman and Mishra (2015) and Deng, Ji and Wang (2017), Green IT is not limited to the creation of energy-efficient IT software applications and hardware. Similarly, it develops sustainable business practices, enhances green awareness, and changes people's behavior. However, due to the rapid evolution of IT, an exhaustive list of Green IT practices becomes infeasible. However, the disparity in the level of ecological understanding of IT, makes most IT professionals and users unaware of how and where to start implementing Green IT. For this reason, Green IT practices are still in the early stages, because systemic impacts on the natural environment are still neglected.

Given the theoretical concepts, the following section gives continuity in the presentation of the elements that compose this research, specifically with respect to the methodological procedures used in the collection and analysis of the empirical data.

\section{METHOD}

\subsection{Research Design}

The descriptive method was used to conduct this research, with the data collected in the companies through a survey with a questionnaire composed of closed questions using the five-point Likert scale. It should be noted that in the questionnaire, the interviewee had the option to mark the alternative "no opinion", and, for this reason, the frequency of answers of some statements does not correspond to the total of the sample. The other response options were: $1-1$ totally disagree; $2-1$ partially disagree; 3 - I do not agree or disagree; 4 - I agree partially; 5 - I totally agree. Babbie (1999) presents, as an advantage of the Likert scale, the unambiguity of the response categories, since they are previously determined, thus preventing the respondents from creating their own responses. If this characteristic were not present, it would be impossible to assess the agreement of the relative strengths of the responses of the various respondents.

The questionnaire was elaborate from the reviewed literature, as can be verified in the Chart 1. 


\begin{tabular}{|c|c|c|}
\hline Constructs & Variables & Author \\
\hline \multirow{4}{*}{ 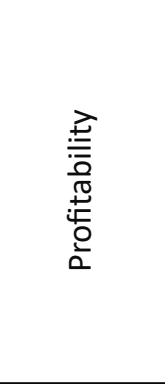 } & $\begin{array}{l}\text { The investments in clean technologies bring economic } \\
\text { long-term benefits. }\end{array}$ & $\begin{array}{l}\text { Molla et al. (2009); Kuo; Dick } \\
\text { (2009) }\end{array}$ \\
\hline & $\begin{array}{l}\text { The company uses some tax incentives offered by govern- } \\
\text { ment agencies. }\end{array}$ & Chen et al., 2011. \\
\hline & $\begin{array}{l}\text { The company uses some power management software in } \\
\text { the computer park. }\end{array}$ & $\begin{array}{l}\text { Melville, 2010; Beloglazov; } \\
\text { Abawajy; Buyya, 2012; Uddin; } \\
\text { Rahman, 2012.) }\end{array}$ \\
\hline & $\begin{array}{l}\text { There are investments in green (sustainable) technologies } \\
\text { to improve the efficiency and agility of IT resources. }\end{array}$ & $\begin{array}{c}\text { Chen et al. (2011); Baumgartner } \\
\text { (2014) }\end{array}$ \\
\hline \multirow{6}{*}{ 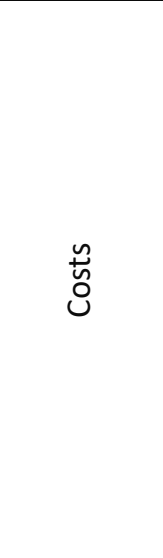 } & $\begin{array}{l}\text { There are actions to reduce costs through the implementa- } \\
\text { tion of sustainable IT initiatives. }\end{array}$ & $\begin{array}{l}\text { Molla et al. (2009); Watson, } \\
\text { Boudreau e Chen (2010) }\end{array}$ \\
\hline & Environmental concerns in IT activities increase costs. & $\begin{array}{l}\text { Benitez-Amado, Perez-Aroste- } \\
\text { gui; Tamayo-Torres (2010) }\end{array}$ \\
\hline & The costs of equipment maintenance are controlled. & Unhelkar (2011) \\
\hline & $\begin{array}{l}\text { Intelligent technology management is an alternative to re- } \\
\text { ducing business operating costs. }\end{array}$ & $\begin{array}{l}\text { Melville (2010); Watson; Bou- } \\
\text { dreau; Chen (2010); Bose; Luo } \\
\text { (2011) }\end{array}$ \\
\hline & $\begin{array}{c}\text { In order to avoid waste, IT equipment has the autonomy } \\
\text { to increase its energy efficiency. }\end{array}$ & Unhelkar (2011) \\
\hline & $\begin{array}{l}\text { The high numbers of waste can be transformed into eco- } \\
\text { nomics by means of ecologically correct practices regard- } \\
\text { ing the use of technology. }\end{array}$ & $\begin{array}{l}\text { Mithas; Khuntia; Roy, 2010; } \\
\quad \text { Molla; Abareshi, 2011; }\end{array}$ \\
\hline \multirow{3}{*}{ 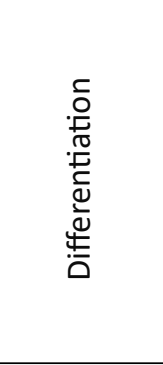 } & $\begin{array}{l}\text { The company has environmental initiatives, as we believe } \\
\text { that this will result in benefits to the image of the organi- } \\
\text { zation before society. }\end{array}$ & $\begin{array}{l}\text { Sheth; Sethia; Srinivas (2011); } \\
\text { Crittenden et al. (2011); Hult } \\
\text { (2011); Dao, Langella e Carbo, } \\
\text { (2011) }\end{array}$ \\
\hline & $\begin{array}{l}\text { The company differentiates itself in the market through } \\
\text { Green IT. }\end{array}$ & $\begin{array}{l}\text { Hunter; Westerman, 2009; Cai; } \\
\text { Chen; Bose, 2013; }\end{array}$ \\
\hline & $\begin{array}{l}\text { Green IT increases market share, or makes it possible to } \\
\text { enter new and more profitable markets. }\end{array}$ & $\begin{array}{l}\text { Cai; Chen; Bose, 2013; Boons; } \\
\text { Lüdeke-freund, 2013; Dezdar, } \\
\text { 2017; }\end{array}$ \\
\hline \multirow{2}{*}{ 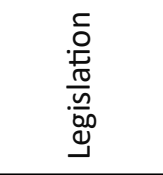 } & $\begin{array}{l}\text { The company uses environmental regulation as an oppor- } \\
\text { tunity to innovate in processes and operations. }\end{array}$ & Dangelico; Pujari, 2010; \\
\hline & $\begin{array}{l}\text { The adoption of practices linked to environmental sustain- } \\
\text { ability is motivated by legislation. }\end{array}$ & $\begin{array}{l}\text { Molla, 2008: Bose; Luo, 2011; } \\
\quad \text { Aguinis; Glavas, } 2012\end{array}$ \\
\hline \multirow{7}{*}{ 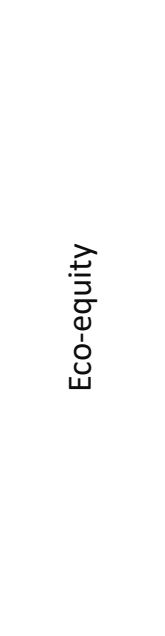 } & $\begin{array}{l}\text { The company is concerned about the impact that IT sys- } \\
\text { tems and equipment have on the environment. }\end{array}$ & $\begin{array}{l}\text { Molla, 2008; Bocken et al., } \\
\text { 2014; }\end{array}$ \\
\hline & $\begin{array}{l}\text { There is some kind of policy for the sustainable use of } \\
\text { resources within the organization, such as diminishing } \\
\text { printing. }\end{array}$ & Dick; Burns (2011) \\
\hline & $\begin{array}{l}\text { As a company, we seek to reduce the environmental im- } \\
\text { pacts that IT activities cause on the environment. }\end{array}$ & Bohas e Poussing (2016) \\
\hline & $\begin{array}{l}\text { The company believes that Green IT can reduce carbon } \\
\text { footprint. }\end{array}$ & $\begin{array}{l}\text { Sarkar; Young (2009); Loos et } \\
\text { al. (2011); Kurkalova e Carterb } \\
\text { (2017) }\end{array}$ \\
\hline & $\begin{array}{l}\text { We use specialized companies for the disposal of electron- } \\
\text { ic equipment. }\end{array}$ & Corbett $(2010)$ \\
\hline & The equipment has a life cycle stipulated by the company. & Brooks; Wang; Sarker (2010) \\
\hline & $\begin{array}{c}\text { The company is concerned about the resources for future } \\
\text { generations. }\end{array}$ & Pollack (2008) \\
\hline
\end{tabular}




\begin{tabular}{|c|c|c|}
\hline \multirow{6}{*}{ 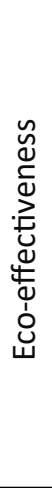 } & $\begin{array}{c}\text { In the company, the initiatives that aim to make IT activi- } \\
\text { ties sustainable are punctual. }\end{array}$ & Chen et al. (2011) \\
\hline & $\begin{array}{c}\text { Reverse logistics of IT equipment is performed, returning } \\
\text { the same to the supplier after use. }\end{array}$ & Mont, 2002; \\
\hline & $\begin{array}{l}\text { The company prefers to purchase equipment that has a } \\
\text { green seal. }\end{array}$ & Corbett, 2010 \\
\hline & The company has some environmental certification. & Hubbard, 2009; \\
\hline & Recycling of electronic equipment is encouraged. & Fairweather (2011) \\
\hline & $\begin{array}{l}\text { The suppliers are evaluated from an environmental point } \\
\text { of view. }\end{array}$ & $\begin{array}{l}\text { Gimenez; Tachizawa, 2012; } \\
\text { Mishra, Akman e Mishra } \\
\text { (2014)>; }\end{array}$ \\
\hline \multirow{3}{*}{ 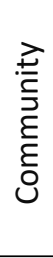 } & $\begin{array}{l}\text { Computers that are outdated for company activities but } \\
\text { still have utility are donated to philanthropy. }\end{array}$ & Molla, 2008; Fairweather, 2011 \\
\hline & $\begin{array}{l}\text { The adoption of practices linked to environmental sustain- } \\
\text { ability is motivated by the pressure of society. }\end{array}$ & Kuo; Dick (2009 \\
\hline & $\begin{array}{l}\text { Proper and safe collection and disposal of e-waste is facili- } \\
\text { tated for employees and the community. }\end{array}$ & Molla, 2008; Fairweather, 2011 \\
\hline \multirow{2}{*}{ 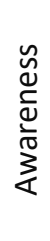 } & $\begin{array}{l}\text { Instructional lectures are offered to employees and the } \\
\text { community in order to guide them in the conscious use of } \\
\text { technology. }\end{array}$ & $\begin{array}{l}\text { Smith; Voß; Grin (2010); Deng; } \\
\text { Ji; Wang (2017) }\end{array}$ \\
\hline & $\begin{array}{l}\text { There are awareness-raising movements of employees } \\
\text { about the importance of using resources, such as energy } \\
\text { and paper, consciously. }\end{array}$ & $\begin{array}{l}\text { Sarkar; Young, 2009; Dick; } \\
\text { Burns, 2011; Baumgartner, } \\
\text { 2014; Deng; Ji; Wang, 2017. }\end{array}$ \\
\hline \multirow{2}{*}{ 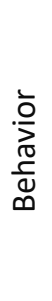 } & $\begin{array}{l}\text { As an individual, my opinion regarding the use of techno- } \\
\text { logy relates exclusively to my personal beliefs. }\end{array}$ & $\begin{array}{l}\text { Mishra; Akman; Mishra } \\
\text { (2014)>; Koo; Chung; Nam } \\
\text { (2015); }\end{array}$ \\
\hline & $\begin{array}{l}\text { Due to the awareness practices adopted by the company, } \\
\text { regarding the correct use of information technologies, I } \\
\text { adopted different positions regarding the use of the tech- } \\
\text { nology in my residence and encouraged friends and family } \\
\text { to do the same. }\end{array}$ & $\begin{array}{c}\text { Mishra; Akman; Mishra } \\
\text { (2014)>; Koo; Chung; Nam } \\
\text { (2015); Deng; Ji; Wang (2017) }\end{array}$ \\
\hline
\end{tabular}

Source: Research data.

The validation stage of the questionnaire was performed using the Delphi technique, which is defined as a systematized method of judging information, designed to obtain the consensus among experts, through articulated validations in phases, which are rounds of review of the questionnaire (Haynes and Shelton, 2018). The number of rounds of the questionnaire usually depends on the nature of the group and its homogeneity. Given that the selection of the experts is considered non-random, for convenience and intentionally, and is justified since the interest is to select specialists in the study theme (Powell, 2003; Landeta, 2006). In this sense, three experts from the area were chosen to form the group of experts and three rounds of the review were required. The experts were: a Doctor of Environmental Quality, a Doctor of Computer Science and a Doctor in Informatics.

After the validation stage with the experts, a pre-test was carried out with eighteen employees from different companies in the IT sector, located in the research focal region. Data were submitted to the Cronbach Alpha coefficient test, in order to verify the internal consistency of the questionnaire elements. This test is used to measure the reliability, that is, to evaluate the magnitude of the correlations in the items of an instrument. It is estimated by means of empirical procedures observing the scores of the investigated subjects (Marco, 2018).

In general, the minimum acceptable value for the reliability of a questionnaire is $\alpha \geq 0.70$. In contrast, the expected maximum value is 0.90 . Values above this maximum indicate redundancy 
in the instrument, requiring the elimination of questions that are measuring the same element of a construct (Streiner and Kottner, 2014). By using the statistical program SPSS ${ }^{\circledR}$ version 20 (Statistical Software for Social Sciences), a value of 0.793 was obtained. Therefore, the result shows acceptable internal consistency for the questionnaire.

After completing the validation phase of the questionnaire, the study population was determined. Data from the Central Business Register (CEMPRE, 2017) indicate that in 2016, the ICT sector in the state of Rio Grande do Sul had 8,893 companies. It should be noted that CEMPRE is formed by companies that are formally constituted and updated annually, based on the economic research of the Brazilian Institute of Geography and Statistics (IBGE) and administrative records, such as the Annual Social Information Report (RAIS).

However, even though the platform from IBGE did not provide the companies' database, the information provided by it was fundamental in the process of population and sample characterization of this research. In this sense, the universe was composed by 5,409 companies, distributed in the 34 cities of the metropolitan region of Porto Alegre. To the detriment of the unavailability of a database, with the e-mails and telephone to contact the companies of the sector of the IT, the search for these data was realized by using the search engine Google. In addition, the information provided by the websites of the commercial associations of the cities covered by this study was searched.

The contact was carried out by e-mail, which contained a brief presentation of the research and an electronic address that led to the questionnaire. The efforts of this stage culminated in the sending of 515 e-mails from April 27 to May 24, 2018. After cleaning the data, to identify the discrepancies of the responses, which are characterized by atypical values, which can range from too low to too high, which corrupt the analyzes, a total of 93 valid questionnaires were obtained.

\subsection{Profile of respondents}

With respect to the companies' profile, micro and small establishments, which totaled 83.9\% of the sample, prevailed. Regarding the sectors of activity of the companies, there was a greater concentration of companies that work with software development, reaching $59.1 \%$ of the sample. Companies in the service sector prevail, with 74 valid responses, followed by the commerce and industry sectors, with 11 and 8 responses respectively.

With regards to the profile of the respondents, directors, managers and members prevailed, 44, 19 and 16 respectively, that is, $85 \%$ of the sample is characterized by professionals in strategic positions. It should be noted that 52 professionals who hold leadership positions are in the IT industry for over 12 years. Of these 52, 34 have been working for more than 12 years in the same company. It was found that 66 professionals occupying leadership positions have undergraduate or postgraduate academic qualifications, 13 of which have only secondary or technical education.

With regards to the 14 respondents who occupy analyst or assistant positions, 9 have undergraduate or postgraduate academic qualifications and 5 have only secondary education, of which 10 have been working for more than 5 years in the IT sector. Based on this information, the sample is characterized by professionals who have experience in the IT sector, and $80 \%$ of the respondents are professionals with a minimum degree in higher education.

\section{RESULTS AND DISCUSSION}

The data are analyzed by means of descriptive statistics, according to the categories of analysis proposed in the research design. Descriptive statistics were calculated with all the asser- 
tions of the data collection instrument, without any categorization, in order to verify which issues obtained the highest and the lowest means and to facilitate the process of data analysis.

Table 1 - Descriptive Statistics

\begin{tabular}{|c|c|c|c|c|}
\hline Construct & Variable & $\begin{array}{l}\text { Mean } \\
\text { value }\end{array}$ & $\begin{array}{l}\text { Standard } \\
\text { deviation }\end{array}$ & Frequency \\
\hline \multirow{4}{*}{ 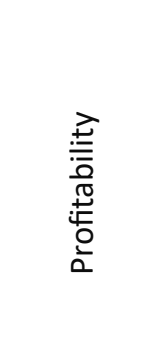 } & $\begin{array}{l}\text { In the company, it is understood that investments in clean } \\
\text { technologies bring economic long-term benefits. }\end{array}$ & 4.38 & 0.975 & 91 \\
\hline & $\begin{array}{c}\text { The company uses some tax incentives offered by govern- } \\
\text { ment agencies. }\end{array}$ & 1.74 & 1.319 & 80 \\
\hline & $\begin{array}{l}\text { The company uses some power management software in the } \\
\text { computer park. }\end{array}$ & 2.13 & 1.53 & 82 \\
\hline & $\begin{array}{l}\text { There are investments in green (sustainable) technologies to } \\
\text { improve the efficiency and agility of IT resources. }\end{array}$ & 3.69 & 1.249 & 80 \\
\hline \multirow{6}{*}{$\stackrel{n}{\tilde{U}}$} & $\begin{array}{c}\text { There are actions to reduce costs through the implementa- } \\
\text { tion of sustainable IT initiatives. }\end{array}$ & 3.67 & 1.361 & 87 \\
\hline & Environmental concerns in IT activities increase costs. & 3.07 & 1.153 & 85 \\
\hline & The costs of equipment maintenance are controlled. & 4.04 & 1.222 & 92 \\
\hline & $\begin{array}{c}\text { Intelligent technology management is an alternative to redu- } \\
\text { cing business operating costs. }\end{array}$ & 4.61 & 0.679 & 92 \\
\hline & $\begin{array}{l}\text { In order to avoid waste, IT equipment has the autonomy to } \\
\text { increase its energy efficiency. }\end{array}$ & 4.15 & 0.829 & 84 \\
\hline & $\begin{array}{c}\text { The high numbers of waste can be transformed into econo- } \\
\text { mics by means of ecologically correct practices regarding the } \\
\text { use of technology. }\end{array}$ & 4.54 & 0.752 & 90 \\
\hline \multirow{3}{*}{ 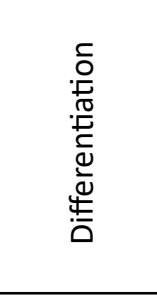 } & $\begin{array}{l}\text { The company has environmental initiatives, as we believe } \\
\text { that this will result in benefits to the image of the organiza- } \\
\text { tion before society. }\end{array}$ & 3.39 & 1.353 & 84 \\
\hline & $\begin{array}{l}\text { The company differentiates itself in the market through Gre- } \\
\text { en IT. }\end{array}$ & 4.08 & 0.711 & 93 \\
\hline & $\begin{array}{c}\text { Green IT increases market share, or makes it possible to en- } \\
\text { ter new and more profitable markets. }\end{array}$ & 3.18 & 0.722 & 93 \\
\hline \multirow{2}{*}{ 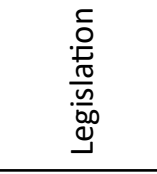 } & $\begin{array}{l}\text { The company uses environmental regulation as an opportu- } \\
\text { nity to innovate in processes and operations. }\end{array}$ & 3.23 & 1.385 & 70 \\
\hline & $\begin{array}{c}\text { The adoption of practices linked to environmental sustaina- } \\
\text { bility is motivated by legislation. }\end{array}$ & 3.19 & 1.322 & 89 \\
\hline \multirow{7}{*}{ 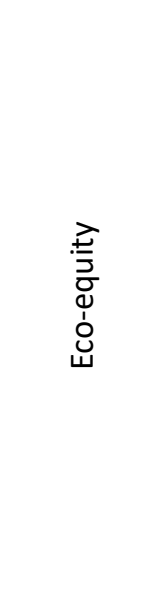 } & $\begin{array}{l}\text { The company is concerned about the impact that IT systems } \\
\text { and equipment have on the environment. }\end{array}$ & 4.46 & 0.854 & 89 \\
\hline & $\begin{array}{l}\text { There is some kind of policy for the sustainable use of re- } \\
\text { sources within the organization, such as diminishing printing. }\end{array}$ & 4.45 & 0.918 & 92 \\
\hline & $\begin{array}{l}\text { As a company, we seek to reduce the environmental impacts } \\
\text { that IT activities cause on the environment. }\end{array}$ & 4.19 & 0.97 & 90 \\
\hline & $\begin{array}{l}\text { The company believes that Green IT can reduce carbon foo- } \\
\text { tprint. }\end{array}$ & 4.19 & 1.045 & 78 \\
\hline & $\begin{array}{l}\text { We use specialized companies for the disposal of electronic } \\
\text { equipment. }\end{array}$ & 3.97 & 1.76 & 93 \\
\hline & The equipment has a life cycle stipulated by the company. & 2.69 & 1.595 & 93 \\
\hline & $\begin{array}{l}\text { The company is concerned about the resources for future } \\
\text { generations. }\end{array}$ & 4.46 & 0.854 & 89 \\
\hline
\end{tabular}




\begin{tabular}{|c|c|c|c|c|}
\hline \multirow{6}{*}{ 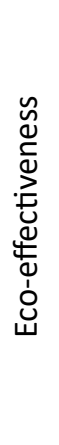 } & $\begin{array}{l}\text { In the company, the initiatives that aim to make IT activities } \\
\text { sustainable are punctual. }\end{array}$ & 3.75 & 1.18 & 89 \\
\hline & $\begin{array}{l}\text { Reverse logistics of IT equipment is performed, returning the } \\
\text { same to the supplier after use. }\end{array}$ & 2.33 & 1.556 & 93 \\
\hline & $\begin{array}{l}\text { The company prefers to purchase equipment that has a gre- } \\
\text { en seal. }\end{array}$ & 4.0 & 1.251 & 93 \\
\hline & The company has some environmental certification. & 1.22 & 0.907 & 93 \\
\hline & Recycling of electronic equipment is encouraged. & 4.35 & 1.185 & 93 \\
\hline & $\begin{array}{l}\text { The suppliers are evaluated from an environmental point of } \\
\text { view. }\end{array}$ & 2.87 & 1.399 & 79 \\
\hline \multirow{3}{*}{ 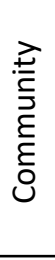 } & $\begin{array}{c}\text { Computers that are outdated for company activities but still } \\
\text { have utility are donated to philanthropy. }\end{array}$ & 4.06 & 1.111 & 93 \\
\hline & $\begin{array}{l}\text { The adoption of practices linked to environmental sustaina- } \\
\text { bility is motivated by the pressure of society. }\end{array}$ & 2.99 & 1.322 & 89 \\
\hline & $\begin{array}{c}\text { Proper and safe collection and disposal of e-waste is facilita- } \\
\text { ted for employees and the community. }\end{array}$ & 3.56 & 1.658 & 93 \\
\hline \multirow{2}{*}{$\frac{\mathscr{y}}{\stackrel{n}{0}}$} & $\begin{array}{l}\text { Instructional lectures are offered to employees and the } \\
\text { community in order to guide them in the conscious use of } \\
\text { technology. }\end{array}$ & 2.05 & 1.37 & 83 \\
\hline & $\begin{array}{l}\text { There are awareness-raising movements of employees about } \\
\text { the importance of using resources, such as energy and pa- } \\
\text { per, consciously. }\end{array}$ & 4.3 & 0.994 & 91 \\
\hline \multirow[b]{2}{*}{ 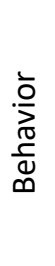 } & $\begin{array}{l}\text { As an individual, my opinion regarding the use of technology } \\
\text { relates exclusively to my personal beliefs. }\end{array}$ & 3.4 & 1.356 & 90 \\
\hline & $\begin{array}{l}\text { Due to the awareness practices adopted by the company, re- } \\
\text { garding the correct use of information technologies, I adop- } \\
\text { ted different positions regarding the use of the technology } \\
\text { in my residence and encouraged friends and family to do the } \\
\text { same. }\end{array}$ & 3.96 & 1.215 & 89 \\
\hline
\end{tabular}

Source: Research data

It is noticed that, in the perception of the respondents, the intelligent management of the technology is an alternative to reduce the operational costs of the business and of wastes with respect to the computer park. However, the average of 2.05 attributed to the assertion "instructive lectures are offered to employees and community in order to guide them in the conscious use of technology", indicates a tendency to centralize the knowledge linked to the intelligent management of technology between the professionals who occupy the management position.

Among the awareness-raising practices adopted by managers, there was a greater tendency to focus efforts on the reduction of energy consumption and the use of resources in a conscious way. In addition, such awareness practices indicate a predisposition in the behavior of individuals, considering the average of 3.96 attributed to the affirmation that, due to the awareness practices adopted by the company, the professional adopted different positions regarding the use of technology in their private decisions.

In the research instrument, the objective of this question was to verify if the individuals changed their behavior with respect to the use of the technologies, to the detriment of the awareness practices established in the companies. Thus, as the statement "my opinion regarding the use of technology relates exclusively to my personal beliefs" received an average of 3.40, that is, below the affirmative that verified whether due to awareness practices as a conscious use of technology, employees tend to adopt the same behavior and awareness in their personal lives, it can be inferred that Green IT practices increase the level of environmental awareness and change the behavior of 
individuals (Akman and Mishra, 2015; Deng, Ji and Wang , 2017).

Regarding the economic perspective, we can see higher averages in the set of issues related to costs, demonstrating that the IT sector's economies in the focal region of this research are more concerned with this issue. Thus, the theoretical assumptions of Pollack (2008), Molla et al. (2009), Mithas, Khuntia and Roy, (2010), Watson, Boudreau and Chen (2010), Melville (2010), Bose and Luo (2011) and Unhelkar (2011), who argue that cost-related aspects are the main motivational factors for the adoption of sustainable practices in IT by companies, configure the reality of the sample investigated.

In addition, one can infer that eco-efficiency, and therefore cost reduction, is obtained by means of the technological update of the computer park, that is, replacement of obsolete equipment with more current technologies or the adoption of technologies for the virtualization of databases. This could be evidenced through the assertions that sought to assess whether respondents understand that "investment in clean technologies bring long-term economic benefits" and "there are investments in green (sustainable) technologies to improve the efficiency and agility of IT resources", which obtained averages of 4.38 and 3.69 , respectively. Initially, these averages may seem low, but in the profitability construct, they were shown to be the most significant.

It should be noted that the average 4.0 attributed to the statement that "the company prefers to acquire equipment that has a green seal" indicates a propensity for companies to relate the technological update to the acquisition of energy-efficient hardware. As pointed out by Elliot (2007) products denominated as sustainable are designed to minimize environmental impacts throughout their life cycle. In this sense, one can infer that the acquisition of energy-efficient hardware, even if motivated by cost reduction, has a positive impact on the environment, corroborating the theoretical bases of Corbett (2010), Melville (2010) and Chen et al. (2011).

In addition, products with energy-efficient seals have reliability among respondents, due to the average 2.87 attributed to the assertion that "the suppliers are evaluated from an environmental point of view". In this sense, it is understood that because green seals meet environmental quality standards and have credibility among the interviewees, they result in benefits for the image of the organizations, thus increasing the competitive advantage in the market in terms of differentiation, resulting in higher revenues and profits (Chen and Chang, 2013, Cai, Chen and Bose, 2013).

It is worth noting that the average value of responses of 4.08 , aimed at asserting that "the company differentiates itself in the market through Green IT" meets the theoretical precepts of Kuo and Dick (2010), Corbett (2010), Cai, Chen and Bose (2013). However, among the variables of the differentiation construct, the averages of 3.18 and 3.39 respectively obtained for the affirmations that "Green IT increases market share" and that the company "has environmental initiatives as it believes that this will result in benefits for the company's image before society", demonstrate that companies do not yet attribute a strategic value for Green IT (Elliot, 2007, Molla et al., 2009, Schmidt et al., 2010, Mishra, Akman and Mishra, 2014).

This finding is due to the fact that the respondents assigned a relatively high average to the question that investigated the perception that companies can differentiate themselves in the market through Green IT, compared to the average 1.22 assigned to the assertion that "the company has some environmental certification". Considering that environmental certifications indicate that the processes of generating products and services respect the legal provisions regarding environmental issues, these tend to be a good indicator regarding the involvement of organizations in the implementation of organizational practices aimed at better environmental alternatives, as well as how much the consumer market considers this relevant issue.

Another little widespread Green IT practice involves the reverse logistics of IT equipment 
(Brasil, 2010), returning them to the supplier after use, which obtained an average of 2.33. In addition, this variable is related to the "concern that companies have with the impact that information technology systems and equipment cause to the environment, as well as the "resources of future generations" that obtained averages of 4.46 , within the eco-equity construct. Once again, it is verified that respondents have an understanding of the environmental and social impacts that organizational activities exert on the environments in which they are inserted, but in practical terms, actions are limited to compliance with legislation (Molla and Abareshi, 2011; Bose and Luo, 2011).

However, companies do not use this perception to differentiate themselves in the market (Cai, Chen and Bose, 2013), more specifically in relation to the reliability aspects of environmental certifications, which result, together with the questions of eco-efficiency and eco-effectiveness, in improving the image of the organization before society (Chen et al., 2011). In this sense, there is a tendency for companies to seek to legitimize themselves as environmentally sustainable, facing the pressures of customers, communities and governments (Sarkar and Young, 2009; Bose and Luo, 2011) and not as a factor of competitive differentiation (Kuo and Dick, 2009; Cai, Chen and Bose, 2013).

Nonetheless, it is important to note that both certifications and the practice of reverse logistics involve additional expenses. In addition, $83.9 \%$ of the companies participating in this research are micro and small-sized, which, in general, cannot invest in certifications, due to the high implantation costs, and thus cannot obtain them. In this sense, the consumer market is the one that exerts the greatest influence at the moment of certification, that is, the choice in relation to certification aims at solving the desire of the main stakeholders (Kuo and Dick, 2009; Chen and Chang, 2013). With regards to reverse logistics, the additional costs concern the expenses that the supplier will have when receiving the used equipment and giving the appropriate destination to them. As a result of increased costs, such a practice may become impractical for small businesses.

It is worth reflecting that, in the construct related to the behavior of individuals with regards to Green IT, the respondents showed a tendency to change their behavior regarding the use and consumption of technology due to awareness practices established in the companies in which respondents can carry out their professional activities (Mishra, Akman and Mishra, 2014; Koo, Chung and Nam, 2015; Deng, Ji and Wang, 2017). In this sense, since individuals are both influenced and influencers of the environment in which they live, one can infer that there is a behavioral pattern established among the consumers of the companies in the sample, since, as they are companies that have an average operating time of 15 years, the differentiation of sustainable practices may not be significant from the point of view of business sustainability.

In this perspective, field research results indicate that compliance with legal requirements, as far as the adoption of practices linked to environmental sustainability, exerts a relatively greater influence than the pressures of customers and companies for ecologically correct practices of the companies, since such variables received averages of 3.19 and 2.99, respectively. However, the average value of answers of 3.23 for the assertion that "the company uses environmental regulation as an opportunity to innovate in processes and operations", demonstrates that companies in the metropolitan area of Porto Alegre are still in the early stages with respect to Green IT practices, because they act restrictively according to legal regulations and do not see opportunities to innovate in products and processes, or even to differentiate themselves in the market.

This finding supports the average of 3.75 for the statement that, "the initiatives that aim to make IT activities sustainable are punctual", and the only practice that presented a relatively significant average refers to the recycling of electronic equipment, with the result of 4.35 . This can be explained by the urban geographic location in which the data collection was carried out, with several 
companies involved in proper collection, dismantling and allocation of electronic components. This situation could probably change if the companies investigated were further away from the metropolitan area.

Thus, it can be inferred that, from an environmental perspective, proper waste disposal is the most recurrent IT practice among the companies investigated, with the majority being directed to companies specializing in the disposal of electronic equipment, with an average of 3.97 found in this variable. On the other hand, considering the social perspective of Green IT, as proposed by Fairweather (2011), the only practice that has proved to be significant among the companies examined is the donation of computers that are out of date for the company's activities, but which still have some utility for philanthropic entities.

\section{CONCLUSION}

The general objective of this research was to analyze the Green IT practices adopted by Brazilian technology-based organizations. In summary, the companies have a reactive behavior with respect to Green IT, since they do not have the objective to increase the general perception of value that the consumers have about the company and neither do they seek a competitive differential based on sustainable development. However, we believe that these results are mainly related to the predominant profile of the companies that participated in the research, that is, small service providers.

In addition, it was found that the implementation of Green IT practices, at first, are motivated by factors linked to cost reduction, compliance with legislation and pressure from different stakeholders. However, it is believed that the aspects linked to the subject's subjectivity are also important and should be considered in this process, since the organization influences the employees' behavior and vice versa. In this sense, the incorporation of norms, assumptions, beliefs and values as a result of environmental policy, propitiate the emergence of a new collective mentality, characterized by the change in organizational behavior and, consequently, in the behavior of individuals.

It is noteworthy that the results obtained indicate possibilities for the continuity of the research line. In this sense, it should be noted that the need for greater energy efficiency and, consequently, saving tangible costs in IT operations, are the main factors for the adoption of Green IT. Therefore, in terms of motivation, the long-term continuous economic value influences the engagement of Green IT practices at the organizational level. Although several studies have been carried out, in terms of energy conservation and cost reduction arising from the implementation of Green IT practices, they are restricted to theoretical models.

Therefore, based on the results of this study, it was found that empirical research that measures the cost reduction resulting from Green IT initiatives, the operational performance or the market value of companies, are scarce in the current literature. In this perspective, Bose and Luo, (2011) recognize that it is difficult to obtain this type of information through field research, due to the difficulty in conducting data collection with companies. Thus, it is suggested that universities and public bodies work together in order to mobilize companies to make their information available, in a confidential manner, for the production of new knowledge. Government involvement can also provide further studies at the level of society, as investigations into the social benefits of implementing Green IT are rare.

Finally, although this research has achieved the proposed objectives and that methodological rigor has been pursued, the existence of limitations, which is based on the Likert-type scale, cannot be exempted from the data collection instrument. This technique registers the level of agree- 
ment or disagreement with a previously formulated statement, based on the ex-ante theoretical review. As only one employee of each company was asked, and even if selection criteria were used for the interviewee's position, the respondent's bias should be considered, as well as the reduction of reality, which is the characteristic of the survey-type research.

\section{REFERENCES}

AKMAN, I., \& MISHRA, A. (2015). Sector diversity in green information technology practices: technology acceptance model perspective. Computers in human behavior, 49, 477-486.

AGUINIS, H., \& GLAVAS, A. (2012). What we know and don't know about corporate social responsibility: A review and research agenda. Journal of management, 38(4), 932-968.

ASADI, S., \& DAHLAN, H. M. (2017). Organizational research in the field of Green IT: A systematic literature review from 2007 to 2016. Telematics and Informatics, 34(7), 1191-1249.

BABBIE, E. (1999). Métodos de pesquisas de survey (Vol. 1). Belo Horizonte: Ed. da U

BARDIN, L. (2016). Análise de conteúdo. São Paulo, SP: Edições 70, 2016.

BOHAS, A., \& POUSSING, N. (2016). An empirical exploration of the role of strategic and responsive corporate social responsibility in the adoption of different Green IT strategies. Journal of cleaner Production, 122, 240-251.

BOSE, R., \& LUO, X. (2011). Integrative framework for assessing firms' potential to undertake Green IT initiatives via virtualization-A theoretical perspective. The Journal of Strategic Information Systems, 20(1), 38-54.

BRASIL. (2010). Lei no 12.305, de 2 de agosto de 2010. Institui a Política Nacional de Resíduos Sólidos (PNRS); altera a Lei no 9.605, de 12 de fevereiro de 1998; e dá outras providências. Retrieved from: < http://www.planalto.gov.br/ccivil_03/_ato2007-2010/2010/lei/l12305. htm>. Access: 25 Oct 2018.

BUTLER, T. (2011). Compliance with institutional imperatives on environmental sustainability: Building theory on the role of Green IS. The Journal of Strategic Information Systems, 20(1), 6-26.

BRUNDTLAND, G. H., KHALID, M., AGNELLI, S., AL-ATHEL, S., \& CHIDZERO, B. J. N. Y. (1987). Our common future. New York, 8.

CAI, S., CHEN, X., \& BOSE, I. (2013). Exploring the role of IT for environmental sustainability in China: An empirical analysis. International Journal of Production Economics, 146(2), 491-500.

CHEN, A. J. BOUDREAU, MC., \& WATSON, R.T. (2008). Information systems and ecological sustainability. Journal of Systems and Information Technology, Sustainability and Information Systems, v. 10, n. 3, p. 186-201.

CHEN, A. J., WATSON, R. T., BOUDREAU, M. C., \& KARAHANNA, E. (2011). An institutional perspective on the adoption of Green IS \& IT. Australasian Journal of Information Systems, 17(1).

CHEN, Y. S., \& CHANG, C. H. (2013). Greenwash and green trust: The mediation effects of green 
consumer confusion and green perceived risk. Journal of Business Ethics, 114(3), 489-500.

CHUNG, Y. L. (2015). Energy-saving transmission for green macrocell-small cell systems: A systemlevel perspective. IEEE Systems Journal, 11(2), 706-716.

CORBETT, J. (2010). Unearthing the Value of Green IT. In ICIS (Vol. 198, pp. 1-22).

DANGELICO, R. M., \& PUJARI, D. (2010). Mainstreaming green product innovation: Why and how companies integrate environmental sustainability. Journal of business ethics, 95(3), 471

DENG, Q., JI, S., \& WANG, Y. (2017). Green IT practice disclosure. Journal of Information, Communication and Ethics in Society.

DIAS, G. F., RAMOS, A. S., SOUZA NETO, R. A. D., \& BASTOS, E. D. M. (2017). Tecnologia da informação verde: Estudo à luz da teoria crença-ação-resultado. Revista de Administração de Empresas, 57(6), 585-600.

DICK, G. N., \& BURNS, M. (2011, March). Green IT in small business: an exploratory study. In 14th Southern Association for Information Systems Conference (pp. 25-26).

DOLCI, D. B., LUNARDI, G. L., SALLES, A. C., \& ALVES, A. P. F. (2015). Implementation of green IT in organizations: a structurational view. Revista de Administração de Empresas, 55(5), 486-497.

DYLLICK, T., \& HOCKERTS, K. (2002). Beyond the business case for corporate sustainability. Business strategy and the environment, 11(2), 130-141.

ELKINGTON, J., \& BURKE, T. (1987). The green capitalists: How to make money-and protect the environment. V. Gollancz.

ELLIOT, S. (2007). Environmentally sustainable ICT: a critical topic for IS research? PACIS 2007 proceedings, 114 .

FAIRWEATHER, N. B. (2011). Even greener IT: Bringing green theory and. Journal of Information, Communication and Ethics in Society, 9(2), 68-82.

FANG, C., YU, F. R., HUANG, T., LIU, J., \& LIU, Y. (2015). A survey of green information-centric networking: Research issues and challenges. IEEE Communications Surveys \& Tutorials, 17(3), 1455-14

FUCHS, C. (2008). The implications of new information and communication technologies for sustainability. Environment, Development and Sustainability, 10(3), 291-309.

HANNE, F. Z. (2011). Green-it: Why developing countries should care?. International Journal of Computer Science Issues (IJCSI), 8(4), 424.

HART, S. L., \& MILSTEIN, M. B. (2003). Creating sustainable value. Academy of Management Perspectives, 17(2), 56-67.

HUBBARD, G. (2009). Measuring organizational performance: beyond the triple bottom line. Business strategy and the environment, 18(3), 177-191.

HAYNES, C. A., \& SHELTON, K. (2018). Delphi method in a digital age: Practical considerations for online Delphi studies. In Handbook of Research on Innovative Techniques, Trends, and 
Analysis for Optimized Research Methods (pp. 132-151). IGI Global.

IBGE - Instituto Brasileiro de Geografia e Estatística. (2016). Cadastro Central de Empresas, CEMPRE. Retrieved from:< https://sidra.ibge.gov.br/pesquisa/cempre/quadros/brasil/2018>. Access: 17 Jul 2020.

KOO, C., CHUNG, N., \& NAM, K. (2015). Assessing the impact of intrinsic and extrinsic motivators on smart green IT device use: Reference group perspectives. International Journal of Information Management, 35(1), 64-79.

KUO, B., \& DICK, G. (2010). The greening of organisational IT: what makes a difference? Australasian Journal of Information Systems, 16(2).

KURKALOVA, L. A., \& CARTER, L. (2017). Sustainable production: Using simulation modeling to identify the benefits of green information systems. Decision Support Systems, 96, 83-91.

LANDETA, J. (2006). Current validity of the Delphi method in social sciences. Technological forecasting and social change, 73(5), 467-482.

LUNARDI, G. L., ALVES, A. P. F., \& SALLES, A. C. (2014). Desenvolvimento de uma escala para avaliar o grau de utilização da tecnologia da informação verde pelas organizações. Revista de Administração (São Paulo), 49(3), 591-605.

LUNARDI, G. L., SIMÕES, R., \& FRIO, R. S. (2014). TI Verde: Uma análise dos principais benefícios e práticas utilizadas pelas organizações. REAd. Revista Eletrônica de Administração (Porto Alegre), 20(1), 1-30.

MARÔCO, J. (2018). Análise Estatística com o SPSS Statistics.: 7ạ edição. ReportNumber, Lda.

MELVILLE, N. P. (2010). Information systems innovation for environmental sustainability. MIS quarterly, 34(1), 1-21.

MISHRA, D., AKMAN, I., \& MISHRA, A. (2014). Theory of reasoned action application for green information technology acceptance. Computers in human behavior, 36, 29-40.

MITHAS, S., KHUNTIA, J., \& ROY, P. K. (2010, December). Green Information Technology, Energy Efficiency, and Profits: Evidence from an Emerging Economy. In ICIS (Vol. 11).

MOLLA, A., PITTAYACHAWAN, S., CORBITT, B., \& DENG, H. (2009). An international comparison of Green IT diffusion. International Journal of e-Business Management, 3(2), 3.

MOLLA, A., \& ABARESHI, A. (2011, July). Green IT Adoption: A Motivational Perspective. In PACIS (p. 137).

MOLLA, A., \& ABARESHI, A. (2012). Organizational green motivations for information technology: empirical study. Journal of Computer Information Systems, 52(3), 92-102.

MURUGESAN, S. (2008). Harnessing green IT: Principles and practices. IT professional, 10(1), 24-33.

POLLACK, T. A. (2008). Green and sustainable information technology: a foundation for students. ASCUE 2008 Proceedings, 63-72.

POWELL, C. (2003). The Delphi technique: myths and realities. Journal of advanced nursing, 41(4), 
376-382.

SALLES, A. C., ALVES, A. P. F., DOLCI, D. B., \& LUNARDI, G. L. (2016). Tecnologia da informação verde: Um estudo sobre sua adoção nas organizações. Revista de Administração Contemporânea, 20(1), 41-63.

SARKAR, P., \& YOUNG, L. (2009). Managerial attitudes towards Green IT: An explorative study of policy drivers. PACIS 2009 PROCEEDINGS, 95.

SCHMIDT, N. H., EREK, K., KOLBE, L. M., \& ZARNEKOW, R. (2010, August). Predictors of Green IT Adoption: Implications from an Empirical Investigation. In AMCIS (p. 367)

STREINER, D. L., \& KOTTNER, J. (2014). Recommendations for reporting the results of studies of instrument and scale development and testing. Journal of advanced nursing, 70(9), 19701979.

UDDIN, M., \& RAHMAN, A. A. (2012). Energy efficiency and low carbon enabler green IT framework for data centers considering green metrics. Renewable and Sustainable Energy Reviews, 16(6), 4078-4094.

UNHELKAR, B. (2016). Green IT strategies and applications: using environmental intelligence. CRC Press.

WATSON, R. T., BOUDREAU, M. C., \& CHEN, A. J. (2010). Information systems and environmentally sustainable development: energy informatics and new directions for the IS community. MIS quarterly, 23-38. 


\section{AUTHORS}

\section{Vanessa Theis}

Doctor in Environmental Quality at FEEVALE University. Novo Hamburgo, Rio Grande do Sul, Brazil.

E-mail: vanessat@feevale.br

ORCID: https://orcid.org/0000-0002-5100-7574

\section{Dusan Schreiber}

Doctor in Administration from UFRGS. Is currently associate professor and researcher at Feevale University, in the PPG in Environmental Quality. Novo Hamburgo, Rio Grande do Sul, Brazil

E-mail: dusan@feeval.br

ORCID: http://orcid.org/0000-0003-4258-4780

\section{Contribution of authors.}

\begin{tabular}{|l|c|c|}
\hline \multicolumn{1}{|c|}{ Contribution } & [Author 1] & [Author 2] \\
\hline $\begin{array}{l}\text { 1. Definition of research problem } \\
\text { 2. Development of hypotheses or research questions (empirical } \\
\text { studies) }\end{array}$ & $\mathrm{V}$ & $\mathrm{V}$ \\
\hline $\begin{array}{l}\text { 3. Development of theoretical propositions } \\
\text { (theoretical work) }\end{array}$ & $\mathrm{V}$ & $\mathrm{V}$ \\
\hline 4. Theoretical foundation / Literature review & $\mathrm{V}$ & $\mathrm{V}$ \\
\hline 5. Definition of methodological procedures & $\mathrm{V}$ & \\
\hline 6. Data collection & $\mathrm{V}$ & $\mathrm{V}$ \\
\hline 7. Statistical analysis & $\mathrm{V}$ & \\
\hline 8. Analysis and interpretation of data & $\mathrm{V}$ & $\mathrm{V}$ \\
\hline 9. Critical revision of the manuscript & $\mathrm{V}$ & $\mathrm{V}$ \\
\hline 10. Manuscript writing & $\mathrm{V}$ & \\
\hline 11. Other (please specify) & $\mathrm{V}$ & $\mathrm{V}$ \\
\hline
\end{tabular}

